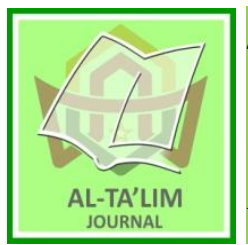

AL-TA'LIM JOURNAL, 25 (1), 2018, (45-55)

(Print ISSN 1410-7546 Online ISSN 2355-7893)

Available online at http://journal.tarbiyahiainib.ac.id/index.php/attalim

\title{
Fiqh Learning For Elementary School Students in Kutamakmur North Aceh: A Study on Students' Ability in Learning Shalat
}

Received: $21^{\text {th }}$ January 2018; Revised:13 ${ }^{\text {th }}$ February 2018; Accepted: $28^{\text {th }}$ February 2018

Permalink/DOI: http://dx.doi.org/10.15548/jt.v25i1.399

\section{Umar Latif *)}

Universitas Islam Negeri Ar-Raniry, Aceh, Indonesia.

E-Mail: umarlatif1945@gmail.com

\section{Nurainah}

Universitas Serambi Mekkah Banda Aceh, Indonesia

E-mail: nura2617@gmail.com

*) Corresponding Author

\begin{abstract}
Fiqh learning is a part of learning process in PAI (Islamic Education) subject given to students especially the elementary ones. It is the responsibility of all teachers and parents to provide the children's needs, clothing, as well as Islamic education. However, from the field observation, some of parents pay little attention to their children's religious education as if such education were only the responsibility of formal educational institution. This present research aims to investigate what the level of elementary school students' understanding on shalat is, how the process of fiqh learning is conducted, and what obstacles the teacher encounter in this learning. This research uses analytical descriptive method with the approach of library research and field research. The data were collected through observation, interview, and field research. The findings of this research reveal that some students in 2 elementary schools; SDN 2 and SDN 6 have not yet understood the concept of shalat; some of them are not able to recite and memorize do'a in. On the other hand, students in SDN 1 Kutamakmur has understood the concept and process of shalat and are able to recite and memorize do'a in shalat. The process of fiqh learning in SDN 2 and SDN 6 Kutamakmur North Aceh has not yet run properly because some students are not able to memorize do'a in shalat as it is expected. The obstacles the teachers encounter is the limited time availability to do practice in school, the lack of parents' guidance in teaching and urging their children to do shalat. Hence, students only learn this at school without parents' guidance and some of students are not able to recite and memorize do'a in shalat.
\end{abstract}

Keywords: Learning; Fiqh; Shalat

How to Cite: Latif, U. Nurainah, N. (2018). Fiqh learning for elementary school students in Kutamakmur North Aceh: A study on students' ability in learning shalat). Al-Ta Lim Journal, 25(1). doi:http://dx.doi.org/10.15548/jt.v25i1.399

\section{INTRODUCTION}

Education is a conscious effort undertaken by family, community and government through guidance, teaching and training activities inside and outside schools (Langford, 2010; Peters, 2010). Education is programmed learning experiences in the form of formal, non formal and informal education, aiming to optimize individuals' abilities in order to live their life in the future (Falk, 2005; Hall, 2009; Merriam, Caffarella, \& Baumgartner, 2012; Mudiyaharjo, 2002). 
The national educational goals entails the description an ideal human in accordance with the world view held by the nation. This goal may be different from one nation to another because of different view of life. Nevertheless, the nature of education in every nation is the same, which is to achieve the realization of a good, healthy, strong, skilful, intelligent, and kind hearted human. In its course of development, the term education means guidance or help given deliberately to the students to assist them achieve maturity. Furthermore, education means the work carried out by a person or group of people to influence a person or group of persons to become mature / attain a higher level of living and livelihood in a mental sense. Thus, education is every effort in association with children to lead their physical and spiritual development toward maturity (Association, 2003; Bruner, 2009; Dewey, 2004; Hill \& Pargament, 2008; Neihart, Reis, Robinson, \& Moon, 2002; Ramayulis, 2002).

Zakiah (1992) states that the responsibility of children's education deos not fully rely on parents and family, especially related to science. Hence, they need to educated to school. Thus, education in schools is a part of education in the family, as well as a continuation of family education. Sending children to school will establish the relationship between home and school because these two environments share the same object and goal, namely to educate children (Christenson \& Sheridan, 2001; Kim, 2009).

According to Epstein (2010), mutual cooperation between family and school environment is very important. This cooperation is only achieved if these two components mutually cooperate. Religion as the foundation of the human life plays a very big role in the process in their life. Religion has regulated the pattern of human life both in relation to God and in relation others. Religion always teaches the best morality, and in its nature will never mislead its adherents. Hence, it is important to teach children about religion to prepare them to face any future obstacles in their life. This education will provide them with guidance as how to behave properly so that they will not trapped in misconduct of whatsoever.

Religious education is an educational system encompassing all aspects of life needed by mankinds to increase their religious internalization and practice in their society, religion, nation and state. Religious education is also a form of guidance for students so they can understand, live and practice the teachings of Islam and make it as their world view in living their life in the world and in the hereafter (Arief, 2002; Azra, 1999; Mujib, Mujib, Mudzakkir, \& Mudzakkir, 2007)

From the above explanation, it can be said that Islamic religious education is physical and spiritual guidance given to children based on the Qur'an to help them attain a perfect Muslim personality. In order have a noble character, it is expected for these students to focus their attention to religiousbased lessons as a means of controling their life.

Slameto (2003); Sudjana (2010) mentions that teaching and learning activities is highly fundamental in school education. It implies that the success or failure of the achievement of educational goals depends heavily on how the learning process experienced by students. In addition, the success to achieve the goal depends not only on the process but also on the interaction (Saiful Bahri Djamarah, 2000; Syaiful Bahri Djamarah, 2002, 2004, 2004; Zain \& Djamarah, 2006).

When the educational interaction takes place, the teacher must be sincere in be having and doing and understanding the students with all the consequences. All obstacles that hinder the process, whether that stems from the behavior of students or others, must be tackled because the success of educative interaction is more determined by the teacher in managing the class. 
In addition, the duty and responsibility of the teacher are to provide a number of norms to the students in order to make them aware of moral and immoral actions. All the norms should be given not only in the classroom but also moutside the classroom. The teachers should the role model through their attitude, behavior and deeds because ideally education is done both with words and behaviors.

One of the such moral examples is the application of worship values such as shalat is one of the subject matter in fiqh because it is the identity of Muslim which they must adhere to. It is an obligation imposed on every mukallaf. Lesmana, Isnanto, \& Widianto, (2016); Ridho (2015); Wibisono \& Hood, (2015) explains that shalat is a major obligation for every Muslim. This worship must be performed everyday and cannot be delegated to others. If this worship is not performed, it will cause a grave sin.

Ridho (2015); Wibisono \& Hood (2015) proposes that shalat is an act initiated by the takbiratul ihram and ended by salam. Shalat also has physical and spiritual benefits. This is acceptable because all shalat movements contain health elements. Chodijah (2017); Saniotis (2015) states that when a person performs a shalat with the true meaning, it will be effective to realize tanha 'anil fakhsyai wal munkar, through which peaceful and harmonious society will be established. Preventing the vicious and wrong act is the purpose of the shalat itself.

In some elementary schools of Kutamakmur, students had studied the fiqh subjects specifically about shalat. However, the fact remains that students were lack of awareness about the obligation to perform shalat. They were not willing to perform shalat when instructed by the teacher and their parents (Akhmad Jayadi \& Dev, 2013; Fauzan, 2017; Khan, 2002; Kheruniah, 2013).

Furthermore, there were still many students who did not understand how to perform shalat. This situation is due to several factors, such as the less educated TV programs that children watch without parents' supervision of parents on television, social circumstances and so forth. In addition, it is also influenced by the students' ability to learn and understand the problem of shalat. To overcome and to build students ability in fiqh learning especially about shalat, it is necessary for teachers to make efforts of a teacher so that students are able to carry out such religious orders. Based on the facts above, the researcher is interested in examining more about Fiqh learning for elementary school students in Kutamakmur North Aceh: A study on students' ability in learning shalat.

\section{METHOD}

This research uses qualitative with descriptive approach. It was conducted in elementary schools in Kutamakmur North Aceh. The number of elementary schools in this area is 28 schools with the number of students approximately 4704 students. Due to this large number of population, the researcher selected 50 students 17 from SDN 1, 17 from SDN 2, and 16 from SDN 6 of Kutamakmur North Aceh. Five teachers of PAI subject from these three schools were also studied. As proposed by Arikunto (2002) if the population is less 200 persons, then all of them can be selected. If it is more, the researcher can select 10\%, 15\%, 20\%, 25\%, and $50 \%$. To obtain accurate data, the researcher uses library research and field research. The data were collected through observation, interview, questionnaire, and documentation. The data were analyzed by referring to the steps proposed by Miles, Huberman, \& Saldana (2013), which consist of data reduction, presentation, and conclusion or verification.

\section{RESULTS AND DISCUSSION}

In SDN 2 and 6, students' ability and understanding in learning fiqh shalat has not yet reached the target. It occurs because of the limited hours of practice in school, so it results in students' low level of understanding fiqh shalat is. Some students are not able to 
recite do'a in shalat. In addition, students also do not try to practice at home to increase their understanding of fiqh shalat. Students only learn this at school during PAI lessons, without any support from other circumstances such as family. On the other hand, in SDN 1 Kutamakmur North Aceh, most of the students are able to understand and memorize the du's in shalat. It is probably due to the fact that they have perseverance in repeating and practicing it at home, considering the hours of practice in school is still lacking.

The learning process of fiqh shalat at SDN 2 and SDN 6 in Kutamakmur North Aceh has not been fully implemented. There are many students who have not been able to memorize do'a in shalat, and lack of cooperation between parents' and teacher is also found, thus impacting the learning outcomes. On the other hand, learning process of fiqh shalat at SDN 1 Kutamakmur subdistrict North Aceh regency has been run properly and well. This is because many students are able to read and memorize do'a in shalat. Teachers familiarize them to practice it through performing dhuhur congregated Furthermore, parents always asks ntheir children to practice and do shalat at home. Hence, students are accustomed to praying, remembering and memorizing do'a in shalat.

Teachers experience some obstacles in learning fiqh shalat for students of SDN in in Kutamakmur North Aceh, some of which are limited hours of school practice, lack of guidance from parents in teaching and practicing about shalat, students' inability to memorize do'a in shalat.

\section{Sources of Fiqh and its Object of Study}

Tasmara (2000) mention that there are two general sources of fiqh the Qur'an and hadith. In the Qur'an the word shalat is mentioned 98 times in 90 different verses. The meaning of the word is shalat (most of the verses of the Qur'an), shalawat (al-Ahzab: 57), grace (al-Ahzab: 44), place of Jewish worship (al-Hajj: 41), -Tealed: 99, 103), blessings (al-Baqarah: 158).

According to Jamaluddin (2008) the dalil of fiqh shalat can be found in Quran some of which are as follows:

(1) "And establish prayer and give zakah and bow with those who bow [in worship and obedience]. "(QS. al-Baqarah: 43); (2) "and establish prayer and give zakah, and whatever good you put forward for yourselves - you will find it with Allah. Indeed, Allah of what you do, is Seeing." (QS. alBaqarah:110); (3) "[O Muhammad], tell My servants who have believed to establish prayer and spend from what We have provided them, secretly and publicly, before a Day comes in which there will be no exchange, nor any friendships." (QS. Ibrahim: 31); (4) "...there will be among you those who are ill and others traveling throughout the land seeking [something] of the bounty of Allah and others fighting for the cause of Allah. So recite what is easy from it and establish prayer and give zakah and loan Allah a goodly loan....."(QS. Muzammil: 20); and (5) "And establish prayer and give zakah and obey the Messenger - that you may receive mercy." (QS. An- Nur: 56).

The above verses instruct the people to establish shalat; the order to perform shalat in congregation, , the assurance of to prevent from the act of fakhsya and munkar, the order to maintain the shalat perfectly and the order to perform shalat at the appointed times. The above verses, described by the Messenger of Allah (may Allaah be pleased with him) said that the Prophet (peace and blessings of Allaah be upon him) said that:

(1) "From Ibn Mas'ood, The Messenger of Allaah (blessings and peace of Allaah be upon him) said: "Teach your children to pray when they are seven years old, and smack them (lightly) if they do not pray when they are 10 years old, and separate them in their beds." (HR. Abu Daud, 1952: 290); and (2) "From $A b u$ Abdurrahman, Abdullah bin Umar bin Al-Khottob radiallahuanhuma dia berkata: The Messenger of Allah (peace 
and blessings of Allah be upon him) said: "Islam is built on five (pillars): bearing witness that there is no god except Allah and that Muhammad is the Messenger of Allah, establishing prayer, paying zakaah, Hajj and fasting Ramadaan.", (HR. Turmuzi dan Muslim).

The above mentioned hadith explains that shalat is the pillar of Islam. The person who establish the shalat establish the pillars of religion. If these important pillars are not established, the construction of Islam can not stand in the real sense.

The Sunnah is seen in terms of being in the position after the Qur'an. It means a mujtahid does not return to the sunnah in discussing the law of an event, except after he do not get the such law in the Qur'an. Similarly, sunnah as a source of fiqh shalat, its position to acknowledge and strengthen a law mentioned in the Qur'an. In addition, the sunnah has position on explaining the Qur'an, which interprets the mujmal, attributing the absolute or common ones. As the order of shalat, Qur'an does not explain its procedure. In this case, the hadith acts as a mubayyin for the Quranic dalil that is still common.

\section{The Study of Fiqh Shalat}

The field of figh is every act of Mukallaf (an adult who is obliged to carry the religious law), to its action determined what law to impose. For example, buying and selling, shalat, fasting and so forth. If such religious acts meet the rules and requirements of Islam, then they are legitimate. Performing shalat and fasting mean fulfilling the obligations of syara`. Thus, every act of mukallaf which is a fiqh object has a legal.

The author of the NAD Province Education Office (2002: 82-95) formulates object of the study of fiqh shalat for basic education: (a) five time shalat (shalat fardh); (b) athan and iqamah; (c) the conditions of shalat; (d) shalat in congregation; (e) Friday shalat; (f) do'a in shalat; (g) do'a after shalat; (h) shalat for the sick; (i) sunnah shalat; (j) taraweeh and witr shalat; (k) 'idaini shalat; (l) tahahjjud shalat; (m) jama' and qashr shalat; and (n) sahwee

The study of fiqh shalat for basic education is aimed to educate students to be able to perform shalat fardh' and accustomed to implement it in everyday life. On the basis of fulfilling this purpose, the scope of fiqh shalat for elementary school encompasses things done before the shalat, such as adzan and iqamah, as well as the material on the terms of shalat which includes study of thaharah (bath, wudhu, tayammum and eliminating najeez). Other objects of study the do'a in shalat and process of shalat including the activities performed in the shalat, the process shalat for the traveler and the sick, and other related material sunnah shalat.

Based on the above description, it can be concluded that the object of study fiqh shalat in elementary school is to teach children about the way to perform shalat, things related to shalat, such as cleaning themselves from big hadast or small hadast, wudhu, bathing, tayamum and things related directly with the practice of shalat such as performing adzan, iqamah, shalat in congregation and so on.

\section{Learning Objectives of Fiqh Shalat}

The objective is something that is expected to be achieved after the activity is completed and requires effort in achieving itl. According to Daradjat (2014), the learning objectives to be achieved in all educational activities, either by teaching or by any other means, include all aspects of humanity, attitudes, behaviors, appearances and views. The purpose of teaching fiqh shalat at elementary level is: (1) students can know the theory and all activities in shalat; (2) students can practice shalat correctly; and (3) students are able to know and memorize do'a in shalat (Hashim \& Langgulung, 2008; Qasmi, 2002).

According to Albantani (2015) learning objectives of fiqh shalat in elementary school are: (1) students can know and understand the basic principles of Islamic 
law in detail and comprehensiveness, both in the form of aqqah and aqli, especially in relating to shalat. Such knowledge and understanding is expected to be the guide of life in his personal and social life; and (2) students can implement and practice Islamic law provisions properly especially in shalat. The practice is expected to foster the obedience of Islamic law, discipline and high responsibility in their personal and social lives.

As for the objectives of learning fiqh shalat in particular is that students are able to explain the provisions of adzan and iqamah and recite adzan and iqamah and demonstrate adzan and iqamah, mentioning the rules of fardhu shalat and practicing activity and $d o$ ' $a$ in shalat including Friday shalat, jama' and qashr shalat, and shalat for the sick. Students are also expected to understand and pronounce $d z h i k r$ and $d o$ 'a after shalat. In addition, students are also expected to know and practice shalat in everyday life.

\section{Learning Materials of Fiqh Shalat in Elementary School}

In the Process of teaching and learning, children are the subject and object of teaching activities. Therefore, the core of the teaching process is the learning activities to achieve the goal. Learning is a process of planned activities to condition someone or a group of people to learn well. The element of learning is a student.

Fiqh lessons in Elementary School are a part of the PAI subject directed to prepare learners to recognize, understand, appreciate, and practice Islamic law, which then becomes the basis of their life view, through guidance activities, teaching, training and experience use (Hasanah, 2017; Prastowo, 2016). The materials of fiqh shalat are as follows:

1. The Pillars of Islam : (a) the meaning of shahadah; and (b) the definition of Shahadaha Tawheed and shahadah rasool;

2. Five-time shalat (fardhu shalat): (a) the names of five shalat times; (b) the number of rak'ahs of five shalat; and (c) shalat times;

3. Adzan and Iqamah, in this chapter which is the discussion are: (a) the words of adzan and the words of iqamah; (b) the meaning of the recitation of adzan and iqamah words; (c) the answer of every recitation of adzan and iqamah; and (d) do'a after adzan and iqamah

4. Shalat conditions: (a) the obligatory requirement of shalat; (b) the legal requirement of shalat; and (c) the things invalidating shalat;

5. Shalat in congregation: (a) the way of shalat in congregation; (b) the legitimate requirement of the imam; (c) the order of makmum; (d) how to inform incorrect Imam; (e) shalat procedures for masbuk; and (f) the priority of shalat in congregation;

6. Friday shalat: (a) Friday shalat time; (b) things done before Friday shalat; (c) process Friday shalat; (d) the law of Friday shalat; and (f) legitimate requirement of Friday shalat;

7. Do'a in shalat (a) do'a iftitah; and (b) do'a qunut;

8. Do'a after shalat;

9. Shalat for the sick: (a) the process of shalat for those who are unable to stand; (b) the process of shalat for those who cannot sit; (c) shalat practice for the sick;

10. Rawateeb Shalat: (a) the meaning of rawateeb shalat; (b) the time and number of rawateeb shalat; (c) performing rawateeb; and (d) the benefits of rawateeb shalat;

11. Taraweeh and witr shalat: (a) the meaning of Taraweeh and witr shalat; (b) the time and number of the rak'ah of Taraweeh and witr shalat; (c) the arrangement of Taraweeh and witr shalat; and (d) the priority of Taraweeh and witr shalat;

12. 'Idainin shalat: (a) sunnah of 'Idainin shalat; (b) time of 'Idainin shalat; (c) the law of 'Idainin shalat; and (e) good deeds in religious festival;

13. Tahajjud shalat: (a) the time and number of tahajjud shalat; (b) the way and do'a 
of tahajjud shalat; and (c) difference of tahajjud shalats with witir shalat;

14. Jama' and qashar shalats, in this chapter the material presented are: (a) the meaning of jama' and qashar shalat; (b) the possibility to do jama' and qashar shalat; (c) how to do jama' and qashar shalat; (d) jama' taqdeem and jama' takheer and (e) practice of jama' and qashar shalat;

15. Sujud sahwi and shukr: (a) the reasons for prostration and prostration; (b) the execution of sujud sahwi and shukr; (c) $d o ' a$ in sujud sahwi and shukr; and (d) the time of sujud sahwi and shukr.

The materials of fiqh shalat taught at elementary school level are aimed at students to be able to cultivate and develop interest in knowing and studying Islamic sharia to apply to their e life, growing curiosity towards Islamic sharia, growing awareness and responsibility in practicing Islamic sharia in daily life, especially in shalat .

Based on the above description, it can be concluded that the material taught in general is in line with the goals and objectives to be achieved from fiqh shalat education at the elementary level. The material taught starts with the provision of students about the theory of Islamic identification in general, then purported to be specialized in shalat materials including practice of shalat.

\section{The Teaching Method of Fiqh Shalat}

Zakiah (1992) mentions that methods are part of an instructional strategy. However, not all methods are used to achieve certain goals. Abrahams \& Millar (2008) concludes that the learning method is a way of presenting teaching materials in order to process student learning in an effort to achieve the goal. Hamdayama (2014); Prastowo (2011) says that the method is a way that teachers can use in learning how to interact in the learning process. In addition, Sani (2014); Sumiati (2009) also mentions that the method is a method that contains the standard procedures for conducting education activities, especially the presentation of material to the students. Teaching methods are diverse, with a variety of considerations, teachers must be able to choose and utilize effective methods in accordance with the material and learning goals. The method emphasizes the active learning process of students in an effort to acquire the learning outcomes.

Boeree (2008) mentions that in the learning process, teachers are required to design a variety of methods that enable the learning process to be effective, creative, innovative and fun. There are several methods known in teaching, such as lecture methods, demonstration methods, task assignment methods, experimental methods, questioning methods, and so on. By selecting the right method, a teacher will be able to determine the output / results of graduates from educational institutions. It is also the foundation of the success of the educational institution. The method used in the teaching fiqh shalat here is a method of demonstration / practice, questioning, discussion, habitation and punishment.

\section{Demonstration Method (Practice) \\ Arifani (2008) asserts that}

demonstration method is a way of learning by showing, showing or displaying something in front of students in the classroom or outside the classroom. In the teaching of fiqh shalat this method can be used to describe the procedure of wudhu, the procedure of performing shalat and the movements in the shalat and do' $a$ in shalat. Ali (2010) says that the application of demonstration methods in the study of fiqh isn't good or effective. There are several steps that must be understood and used by the teacher, consisting of planning, testing and implementing. Rozi (2013) proposed that this is a method providing educational materials either using tools or objects, such as in the demonstration in the hope that it becomes clear and easy for students to practice the material. 


\section{Inquiry Method}

Inquiry method is a way of presenting lesson material through various forms of questions answered by students. These questions can be made at the beginning, in the middle, or at the end of the teaching and learning activities. From the results of question and answer, teachers can clarify students' understanding about a particular subject matter. This method can developt he ability to propose and formulate questions and communication (Richardson \& St Pierre, 2008).

This method can also be used in learning fiqh. Through this method, students who do not understand about materials can directly ask the teachers. Teachers with the application of inquiry methods will usually prepare materials related to materials that will be given later for the students. Thus, the method in learning fiqh shalat help students understand and explore the material given.

\section{Discussion Method}

Discussion is a group activity in solving problems for decision making. In the study of fiqh shalat, it is acceptable for teachers to apply this method. Through this approach, students will be more able and courageous to express opinions. The advantage gained from the implementation of this discussion in the study of fiqh shalat is that students who have not understood certain material will be able to know by way of discussing it. Suryosubroto (2002) states that the purpose of the method of discussion is to inculcate / develop courage to express one's own opinions; seek truth through one another's considerations of opinion; learn to find agreement of opinion through deliberation; and familiarize the students with tolerance.

\section{Habituation Method}

Nafis \& Nafis (2011) says that habituation is one important method of education $t$, especially for children beecause they have not realized what is good in the sense of morality Children need to get used to speaking, learning and working and on a regular basis. Embedding habits is difficult, sometimes taking a long time. However, this should be done so that children can fulfill the work without too much trouble, losing a lot of energy and finding many difficulties.

In other words, supervision is done according to the age of learners, and the need for a balance between supervision and freedom. The method of habituation applied in the study of fiqh shalat will have an excellent impact for the creation of students who are diligent and disciplined in carrying out an obligation. Every act done with the approach of habituation will usually be easier for students to do even though it is hard. However, if every deed is not based on habituation, it will be very difficult to be implemented.

\section{Punishment Method}

Punishment is the worst method but under certain conditions it should be used as well. In figh learning, this method can be used if teachers fail to teach students by other method. It is probably because students are naughty or too arrogant in following the learning process, then the method of punishment becomes a last alternative. Nata, (2016); Roqib (2009) states that punishment is a tool in giving action against any violation of established rules. Punishment as a negative reinforcement if given properly and wisely can be a tool of motivation.

The application of punishment method in learning fiqh shalat only aims to give the impression to the naughty students. Fiqh learning must really applied even with punishment method and usually this method is not applied for a long time but will only be temporary.

\section{CONCLUSION AND RECOMMENDATION}

Students of SDN in Kutamakmur subdistrict North Aceh regency is not yet fully 
able to understand figh shalat. Hence, the learning process does not run as expected in some schools. This is known from the results of research and observation on the three primary schools located in the Kutamakmur subdistrict North Aceh regency. The process of learning fiqh shalat at elementary school in Kutamakmur subdistrict North Aceh regency has not been fully implemented. Many students are not able to read and memorize $d o$ 'a in shalat. Some obstacles in learning fiqh shalat are students' inability to memorize $d o$ ' $a$ in less guidance from parents in teaching and practicing about shalat. Children only learn it in school without any guidance from parents at home and very limited hours of practicing it at schools.

At elementary school in Kutamakmur subdistrict North Aceh regency it is really urgent for students to study of fiqh shalat in depth. Therefore, to provide understanding to students, all parties, especially teachers should be able to determine the material and syllabus in accordance with the level of student understanding. To be able to improve learning process of fiqh shalat at elementary school in Kutamakmur subdistrict North Aceh regency, teachers should provide tasks to memorize do'a in shalat. Furthermore, to be able to overcome obstacles encountered, teachers and parents should be able to build a good cooperation in providing shalat teaching to children both at school and at home.

\section{REFERENCES}

Abrahams, I., \& Millar, R. (2008). Does practical work really work? A study of the effectiveness of practical work as a teaching and learning method in school science. International Journal of Science Education, 30(14), 19451969.

Akhmad Jayadi, S. E., \& Dev, M. E. (2013). The impact of shalat on student's daily behavior and their subjects value: Case studies on Madrasah Diniyah Ma'hadil-Hasyimy, Pragaan, Sumenep. Integrity, 744.
Albantani, A. M. (2015). Implementasi kurikulum 2013 pada pembelajaran bahasa arab di madrasah ibtidaiyah. Arabiyat: Jurnal Pendidikan Bahasa Arab Dan Kebahasaaraban, 2(2), 178-191.

Ali, M. (2010). Penerapan metode demonstrasi dalam meningkatkan prestasi belajar siswa pada mata pelajaran Fikih kelas V di MINU KH. Mukmin Sidoarjo Tahun Pelajaran 2009/2010. Jurnal Penelitian Tindakan Kelas, 1(1).

Arief, A. (2002). Pengantar Ilmu dan Metodologi Pendidikan Islam. Ciputat Pers.

Arifani, I. N. (2008). Metode demontrasi dan eksperimen.

Arikunto, S. (2002). Prosedur Suatu Penelitian: Pendekatan Praktek. Edisi Revisi Kelima. Jakarta: Rineka Cipta.

Association, N. M. S. (2003). This we believe: Successful schools for young adolescents: A position paper of the National Middle School Association. National Middle School Association.

Azra, A. (1999). Pendidikan Islam: tradisi dan modernisasi menuju milenium baru. Logos Wacana Ilmu.

Boeree, G. (2008). Metode Pembelajaran dan Pengajaran. Yogyakarta: Arruzz Media.

Bruner, J. S. (2009). The process of education. Harvard University Press.

Chodijah, S. (2017). The concept of tahajud prayer through psychotherapy approach in relationship with psychological health. in conference Proceeding (p. 324).

Christenson, S., \& Sheridan, S. M. (2001). Schools and families: Creating essential connections for learning. Guilford Press. 
Daradjat, Z. (2014). Metodik Khusus Pengajaran Agama Islam. Bumi Aksara.

Dewey, J. (2004). Democracy and education. Courier Corporation.

Djamarah, Saiful Bahri. (2000). Guru dan anak didik dalam interaksi edukatif. Rineka cipta.

Djamarah, Syaiful Bahri. (2002). Rahasia sukses belajar. Jakarta: Rineka Cipta.

Djamarah, Syaiful Bahri. (2004). Pola komunikasi orang tua dan anak dalam keluarga (sebuah perspektif pendidikan Islam). Rineka Cipta.

Epstein, J. L. (2010). School, family, and community partnerships: Preparing educators and improving schools. Hachette UK.

Falk*, J. H. (2005). Free-choice environmental learning: framing the discussion. Environmental Education Research, 11(3), 265-280.

Fauzan, F. (2017). Analysing the essence of Fiqh subjects in curriculum 2013. AHKAM: Jurnal Ilmu Syariah, 17(1).

Hall, R. (2009). Towards a fusion of formal and informal learning environments: The impact of the read/write web. Electronic Journal of E-Learning, 7(1), 29-40.

Hamdayama, J. (2014). Model dan metode pembelajaran kreatif dan berkarakter. Bogor: Ghalia Indonesia.

Hasanah, U. (2017). Peningkatan hasil belajar mata pelajaran Fiqih melalui penerapan Metode PQRST (Preview, Question, Read, Summarize, Test) peserta didik kelas V di MI Ismaria Al-Qur'aniyah Islamiyah Raja Basa Bandar Lampung tahun pelajaran 2016/2017'. Al-Tadzkiyyah: Jurnal Pendidikan Islam, 8(1), 1-14.
Hashim, C. N., \& Langgulung, H. (2008). Islamic religious curriculum in Muslim countries: The experiences of Indonesia and Malaysia. Bulletin of Education \& Research, 30(1), 1-19.

Hill, P. C., \& Pargament, K. I. (2008). Advances in the conceptualization and measurement of religion and spirituality: Implications for physical and mental health research.

Jamaluddin, S. (2008). Shalat Sesuai Tuntunan Nabi SAW. LPPI UMY, Yogyakarta.

Khan, M. F. (2002). Fiqh foundations of the theory of Islamic economics: a survey of selected contemporary writings on economics relevant subjects of fiqh. Theoretical Foundations of Islamic Economics, 61-86.

Kheruniah, A. E. (2013). A teacher personality competence contribution to a student study motivation and discipline to fiqh lesson. International Journal of Scientific \& Technology Research, 2(2), 108-112.

Kim, Y. (2009). Minority parental involvement and school barriers: Moving the focus away from deficiencies of parents. Educational Research Review, 4(2), 80-102.

Langford, G. (2010). The concept of education. In New Essays in the Philosophy of Education (International Library of the Philosophy of Education Volume 13) (pp. 13-35). Routledge.

Lesmana, H. C., Isnanto, R., \& Widianto, E. D. (2016). Perancangan aplikasi "Sholat Yukk" Pada android sebagai media pembelajaran ibadah shalat anak-anak. Jurnal Teknologi Dan Sistem Komputer, 4(4), 502-509.

Merriam, S. B., Caffarella, R. S., \& Baumgartner, L. M. (2012). Learning 
in adulthood: A comprehensive guide. John Wiley \& Sons.

Miles, M. B., Huberman, A. M., \& Saldana, J. (2013). Qualitative data analysis. Sage.

Mudiyaharjo, R. (2002). Pengantar pendidikan: Sebuah Studi Awal Tentang Dasar-dasar Penddidikan pada Umumnya dan Pendididkan di Indonesia. Jakarta, PT Raja Grafindo Persada.

Mujib, A., Mujib, A., Mudzakkir, J., \& Mudzakkir, J. (2007). Ilmu pendidikan Islam. Kencana Prenada Media Group.

Nafis, M. M., \& Nafis, M. M. (2011). Ilmu Pendidikan Islam. Teras.

Nata, D. H. A. (2016). Ilmu Pendidikan Islam. Prenada Media.

Neihart, M., Reis, S. M., Robinson, N., \& Moon, S. (2002). The social and emotional development of gifted children: What do we know? Sourcebooks, Inc.

Peters, R. S. (2010). The concept of education (international library of the philosophy of education volume 17). Routledge.

Prastowo, A. (2011). Panduan Kreatif Membuat Bahan Ajar Inovatif: Menciptakan Metode Pembelajaran yang Menarik dan Menyenangkan. Jogjakarta: DIVA Press (Anggota IKAPI).

Prastowo, A. (2016). Keselarasan materi fikih MI kurikulum 2006 terhadap karakteristik perkembangan peserta didik. Jurnal Pendidikan Agama Islam, 7(2).

Qasmi, M. K. (2002). Madrasa Education. Mumbai: Markazul Ma 'arif Education \& Research Centre.

Ramayulis. (2002). Ilmu Pendidikan Islam. Kalam Mulia.
Richardson, L., \& St Pierre, E. (2008). A method of inquiry. Collecting and Interpreting Qualitative Materials, 3(4), 473.

Ridho, M. (2015). Islamic Perspective on Child Protection. Lentera, 17(2).

Roqib, M. (2009). Ilmu Pendidikan Islam. PT LKiS Pelangi Aksara.

Rozi, M. F. (2013). Penerapan Teknologi dalam pembelajaran Fiqih di MTs Miftahul Qulub Polagan Galis Pamekasan. Jurnal Tadris STAIN Pamekasan, 6(1), 99-120.

Sani, R. A. (2014). Pembelajaran saintifik untuk implementasi kurikulum 2013. Bumi Aksara.

Saniotis, A. (2015). Understanding mind/body medicine from Muslim religious practices of Shalat and Dhikr. Journal of Religion and Health, 1-9.

Slameto. (1988). Belajar dan Faktor-faktor yang Mempengaruhinya. Bina Aksara.

Sudjana, N. (2010). Belajar dan faktor-faktor yang Mempengaruhinya. Jakarta: Rineka Cipta.

Sumiati, A. (2009). Metode pembelajaran. Bandung: Wacana Prima.

Suryosubroto, B. (2002). Proses belajar mengajar di sekolah. Jakarta: Rineka Cipta.

Tasmara, T. (2000). Menuju muslim kaffah: menggali potensi diri. Gema Insani.

Wibisono, C., \& Hood, H. S. (2015). Shalat Determination Toward Employees Performance.

Zain, A., \& Djamarah, S. B. (2006). Strategi belajar mengajar. Jakarta: Rineka Cipta.

Zakiah, D. (1992). Ilmu Pendidikan Islam. Jakarta: Bumi Aksara. 